\title{
MONETARY DEVELOPMENTS AND EXPANSIONARY FISCAL CONSOLIDATIONS: EVIDENCE FROM THE EMU*
}

\author{
António Afonso ${ }^{\$}$, Luís Martins"
}

2014

\begin{abstract}
This paper provides new insights about the existence of expansionary fiscal consolidations in the Economic and Monetary Union, using annual panel data for 14 European Union countries over the period 1970-2012. Different measures for assessing fiscal consolidations based on the changes in the cyclically adjusted primary balance were calculated. A similar ad-hoc approach was used to compute monetary episodes. Panel Fixed Effects estimations for private consumption show that, in some cases, when fiscal consolidations are coupled with monetary expansions, the traditional Keynesian signals are reversed for general government final consumption expenditure, social transfers and taxes. Keynesian effects prevail when fiscal consolidations are not matched by a monetary easing. Panel probit estimations suggest that longer and expenditure based consolidations contribute positively for its success, while the opposite holds for the tax based ones.
\end{abstract}

Keywords: fiscal consolidation, monetary expansion; non-Keynesian effects, panel data, probit

JEL: C23, E21, E5, E62, H5, H62

\footnotetext{
* We thank participants at the UECE $3^{\text {rd }}$ Conference on Economic and Financial Adjustments for useful comments and suggestions. The opinions expressed herein are those of the authors and do not necessarily reflect those of the ECB or the Eurosystem.

\$ ISEG/ULisboa -Universidade de Lisboa, Department of Economics; UECE - Research Unit on Complexity and Economics, R. Miguel Lupi 20, 1249-078 Lisbon, Portugal, email: aafonso@iseg.utl.pt. UECE is supported by the Fundacão para a Ciência e a Tecnologia (Portuguese Foundation for Science and Technology) through the PEst-OE/EGE/UI0436/2011 project, European Central Bank, Directorate General Economics, Kaiserstraße 29, D-60311 Frankfurt am Main, Germany.

\# Banco de Portugal. email: Luís Martins luis_pedrom@sapo.pt.
} 


\section{Introduction}

Keynesian theory gives us some insights about the expected effect of government budgetary components' changes on income. It postulates that an increase in government spending should stimulate the economy, via the multiplier mechanism, thus increasing disposable income and private consumption. Under this reasoning, an increase in taxation should lead to a decrease in private consumption.

Nevertheless, since the early 90's with the case studies of Denmark and Ireland ${ }^{1}$, some literature has been discussing the possible non-Keynesian effects of fiscal policy, namely during fiscal consolidation periods.

The theoretical underpinnings stemmed from the German Council of Economic experts in their 1981 and 1982 reports and are referred to as the "expectational view of fiscal policy". 2 Arguably, the standard Keynesian relationship between private consumption and government budgetary components may be reversed under certain circumstances. A deterioration of the fiscal position (resulting in a budget deficit) today may lead to an increase in taxation in the future in order to fulfil the government budget constraint, therefore reducing the agents' permanent income. If such expectations are accommodated by the individuals, this could lead to a decrease in private consumption today. The reverse reasoning holds for a fiscal consolidation, meaning that an improvement in the fiscal position may lead to an increase in private consumption today. Some empirical research presents evidence that supports this view. $^{3}$

In fact, the expectational view of fiscal policy relies on the assumption of Ricardian households, which smooth consumption and don't have liquidity constraints. This motivates a thorough assessment of the monetary developments while studying expansionary fiscal consolidations. Moreover, according to the Keynesian view, under the IS-LM framework, a fiscal consolidation may lead to an increase in private consumption if accompanied by a strong enough monetary expansion that offsets the detrimental effects of fiscal policy developments on disposable income and private consumption.

Arguably, while neglecting the monetary policy stance, one could find himself in a situation described by Ardagna (2004): "In this case, the coefficients of fiscal policy variables can be biased, capturing the effect of monetary rather than fiscal policy".

\footnotetext{
${ }^{1}$ See Giavazzi \& Pagano (1990).

${ }^{2}$ See Hellwig \& Newmann (1987).

${ }^{3}$ See for instance, Giavazzi \& Pagano (1990), Perroti (1999), Ardagna (2004), Afonso (2006, 2010) and Alesina \& Ardagna (2013).
} 
The importance of this issue within the Economic and Monetary Union (EMU) context is rather obvious, since the expectational view of fiscal policy was to some extent reflected in the fiscal convergence criteria of the Maastricht Treaty. Additionally, the monetary policy stance is outside the national governments' influence.

This paper contributes to the existing literature by providing some new insights about the importance of the monetary stance for the relationship between fiscal developments and private consumption during fiscal consolidation periods. It does so by expanding notably Afonso's (2006, 2010) and Afonso \& Jalles's (2014) core specification in order to accommodate the monetary policy developments. We conduct an assessment of the fiscal episodes using the same criteria. However, and in addition, we also identify monetary episodes for 14 European Union countries from 1970 to 2012 and study their relationship with fiscal developments.

The paper is organized as follows. Section two reviews the related literature. Section three presents an identification of the fiscal and monetary episodes and their respective relationship. In section four we conduct the empirical analysis of expansionary fiscal consolidations resorting to panel estimations, accommodating the developments of monetary policy, and we also assess the success of the fiscal consolidations. Section five concludes the paper.

\section{Literature survey}

Hellwig \& Neumann (1987) were pioneers regarding the assessment of the expansionary fiscal consolidation hypothesis. They argue that fiscal consolidation in Germany in the 1980's under Chancellor Kohl had such a positive impact on private sector confidence that demand actually increased. Supposedly, fiscal consolidation by the Federal Government and monetary tightness by the Bundesbank led to continued output growth and low inflation. Also lower deficits stimulated private investment in the long run due to reduced cost of financing. Nevertheless, unemployment remained high, which authors attribute to labour market rigidity.

Giavazzi \& Pagano (1990) test this hypothesis for Denmark and Ireland for mid and late 1980's, respectively. For Denmark they report that the thriving in consumption experienced in 1983-1986 cannot be explained by the decline in interest rates alone and that such is related to fiscal consolidation through the increase in revenue from income taxation and decrease in public investment. Regarding the Irish case, the fast consumption growth in the second stabilization was due to the government focus on decreasing spending, instead of 
increasing taxation and also due to the liberalization of the credit markets. As a whole, in these cases the expansionary fiscal consolidation is linked to an adjustment on the public spending side, rather than on revenues, although in Denmark the adjustment was through investment spending and in Ireland it was through current spending.

Alesina \& Ardagna (1998) investigate the expansionary fiscal consolidation possibility recurring to an analysis of OECD countries from 1960 to 1994 . According to the general Council of Economic Experts' expectational view of the fiscal policy, fiscal adjustments occurring when the debt level is high or growing rapidly should be expansionary, whereas others should not. Nevertheless the authors don't find evidence that confirm this view. On the other hand, they found strong evidence of the effect of the composition of the adjustment in the outcome of the fiscal consolidation: all of the non-expansionary adjustments were tax based and all of the expansionary ones were based on expenditure cuts. Expenditure adjustments that were accompanied by wage moderation and by nominal exchange rate devaluation turned out to be expansionary.

Perroti (1999) addresses the same issue for nineteen OECD countries from 1965 to 1994 and, according to his findings, substantial deficit cuts can lead to booms in private consumption. The likelihood of an expansionary fiscal consolidation increases on times of "fiscal stress", which the author defined as periods of high debt-to-GDP ratio or following periods of exceptionally high debt accumulation rates. His findings differ for other periods since in "normal" times the Keynesian effects of a fiscal consolidation (either through spending cuts or tax increases) on private consumption dominate.

Giavazzi et al. (2000) address the issue of expansionary fiscal consolidation in OECD countries from 1973 to 1996 and in developing countries from 1960 to 1995. In OECD countries evidence of non-Keynesian response by the private sector is more likely to be found when the fiscal impulses are large and persistent. This means that only those can signal a regime change, thus affecting private sector expectations. Also non-Keynesian effects leading to an expansionary fiscal consolidation are stronger for changes in net taxes rather than in public expenditure. In developing countries, non-Keynesian effects occur not only during periods of fiscal contractions but also during fiscal expansions and when countries are piling up debt rapidly, regardless of its level.

Using panel data from OECD countries from 1970 to 2002, Ardagna (2004) investigates the effect of fiscal consolidations on debt-to-GDP ratio and GDP growth. Regarding the debt-to-GDP ratio, the success of the fiscal consolidation depends more on the size of the adjustment rather than its composition. On the other hand, the likelihood of a fiscal 
consolidation being expansionary increases when it is based on public spending cuts rather than on increased taxation. Concerning the role of the monetary policy, there was evidence that either successful (leading to decrease in debt-to-GDP ratio) or expansionary (leading to increase in GDP growth) consolidations don't need to be met by expansionary monetary policies nor exchange rate devaluations.

Giudice et al. (2004) address the matter of non-Keynesian effects in fourteen European Union countries in an ex-post and ex-ante analysis. Ex-post analysis consisted on studying the period from 1970 to 2002 and see if fiscal consolidation episodes were followed by an increase in GDP growth. Results show that this occurred in about half the cases. The ex-ante analysis carried out was based on simulations by the European Commission QUEST model and suggested that short-term non-Keynesian effects can occur if consolidation is mainly on the spending side. The latter is also true in the ex-post case, which is in line with most of empirical studies.

Afonso $(2006,2010)$ conducted a panel analysis for 15 EU countries from 1970 to 2005 having found some evidence of non-Keynesian effects in private consumption for some government spending items, namely final consumption and social transfers. Results show that a decrease in government consumption leads to an increase in private consumption in the long run and the magnitude of this effect is higher when a fiscal consolidation episode occurs.

Devries et al. (2011) construct a database for fiscal consolidation measures taken by 17 OECD countries from 1978 to 2009 , based on the premise that computing fiscal consolidations from the changes of the cyclically adjusted primary balance may be problematic. Arguably, such approach may be biased in the sense that it may capture changes that are not related to policy actions due to its inability to remove sharp fluctuations in economic activity. Therefore they identify fiscal consolidations through an historical approach based on policy documents. This database has been used in subsequent literature concerning expansionary fiscal consolidations. ${ }^{4}$

Afonso \& Jalles (2012) analyse a panel of OECD countries from 1970 to 2010 to assess if the composition and duration of fiscal consolidations matter for their success. Consolidation episodes lead to a decrease in the debt ratios only if accompanied by strong economic growth and increased output gap. Increased duration contributes to the success of the fiscal consolidation episode. Moreover, the success of a fiscal consolidation depends on

\footnotetext{
${ }^{4}$ See for instance Afonso \& Jalles (2012) and Alesina \& Ardagna (2013).
} 
the composition of the adjustment: consolidations based mainly on tax increases contribute negatively for its success.

Alesina \& Ardagna (2013) also use Devries et al. (2011) policy action based approach to identify the fiscal episodes for 21 OECD countries from 1970 to 2010 . They conclude that expenditure based adjustments are more likely to be successful and expansionary. Monetary policy is not significant to explain the differences between expenditure based and tax based adjustments.

To sum up, most of the research seems to support or at least not reject the idea of expansionary fiscal episodes. ${ }^{5}$ Also, some findings ${ }^{6}$ suggest that expansionary and successful fiscal episodes are more likely when there is a consolidation on the spending side. Moreover, some of the literature, such as Perroti (1999) and Giavazzi et al. (2000) propose that nonKeynesian effects are more likely or only occur during periods of high debt-to-GDP ratio or when debt is piling up quickly.

\section{Identification of fiscal and monetary episodes in the EMU}

\subsection{Fiscal Episodes}

Most of the empirical literature relies on the change in the cyclically adjusted primary balance (CAPB) as a percentage of GDP as measure of the governments' structural budget balance. It extracts the elements of the primary balance that are due to the business cycle from the total balance in order to have an indicator that has been corrected from the effects of changes in economic activity, thus reflecting the discretionary part of the fiscal policy.

In practice, one can assess the existence of fiscal episodes - either contractions or expansions - by studying the behaviour of this indicator over time. In Giavazzi \& Pagano (1996) there is a fiscal episode when the cumulative change in the cyclically adjusted primary balance is at least 5,4 , or 3 percentage points of GDP in 4,3 or 2 years respectively or 3 percentage points in one year. Alesina \& Ardagna (1998) identify the periods of occurrence of fiscal episodes by looking for the periods when the change in the cyclically adjusted primary balance was greater than 2 percentage points in one year or at least 1.5 percentage points of GDP on average in the last two years. Afonso's (2006, 2010) assessment of fiscal episodes relies on a different method: there is a fiscal episode when the change in the cyclically adjusted primary balance is greater than 1.5 times the panel standard deviation of this

\footnotetext{
${ }^{5}$ As seen in Giavazzi \& Pagano (1990), Alesina \& Ardagna (1998), Perroti (1999), Giavazzi et al. (2000), van Aarle \& Garretsen (2003), Ardagna (2004), Giudice et al. (2004) and Afonso (2006, 2010).

${ }^{6}$ Giavazzi \& Pagano (1990), Alesina \& Ardagna (1998), Afonso (2006, 2010) and Alesina \& Ardagana (2013).
} 
indicator or when the average absolute change in the last two years is greater than the standard deviation of the full panel. Table I shows the fiscal expansions and contractions according to the different criteria.

The measures used by Giavazzi \& Pagano (1996), Alesina \& Ardagna (1998) and Afonso $(2006,2010)$, were labelled respectively as $F E^{1}, F E^{2}$ and $F E^{3}$. Overall there is a considerable overlapping of episodes according to the different criteria: there is a coincidence of 82 and 63 percent between fiscal episodes 1 and 2 and 1 and 3, respectively and 82 percent between criteria 2 and 3 (see Table I).

All the criteria capture the cases studied by Giavazzi and Pagano (1990), as there is an identification of fiscal contractions in Denmark in 1983-86 and in Ireland in 1988. Also, there is a clear identification of fiscal expansions in 2009 across the EMU countries, following the European Commission policy recommendations after the 2007-08 financial crisis. Furthermore, the different methodologies also identify the consolidation efforts made by the countries under financial assistance in 2011-2012, namely Ireland, Greece and Portugal.

[Table I]

Recent studies such as Afonso \& Jalles (2012) and Alesina \& Ardagna (2013) also include a criterion for identifying fiscal consolidations referred to as IMF's "Action Based Approach" computed by Devries et al. (2011). It identifies fiscal consolidations based on an historical approach through the analysis of policy documents. Arguably the CAPB based fiscal consolidations may be biased in the sense that they may capture changes that are not related to policy actions due to its inability to remove sharp fluctuations in economic activity. Unfortunately the database is still under update, so we would have to discard the most recent years (2010-2012) in order to accommodate that approach. Therefore we will not include it at this point, but we intent to do so in future research.

\subsection{Monetary episodes}

One of the main contributions of this paper is the study of the coupling of fiscal and monetary policy in order to assess if monetary expansions have an impact on the relationship between government budgetary components and private consumption during fiscal consolidation episodes. Therefore, it is crucial to establish a clear identification of the monetary episodes in the EMU countries. We chose three indicators that could be used as a 
measure of the monetary stance for the different countries, namely the real short term money market interest rate, and the nominal and real effective exchange rates.

The change in the real short term interest rate is a widely used measure of the monetary policy easing or tightening ${ }^{7}$ as it accounts not only for the money market rates but also for the price developments. Therefore a negative variation in this indicator signals a real monetary easing, rather than a nominal one.

Both the nominal and the real effective exchange rate assess the currency value in a country vis-à-vis a weighted average of other selected countries' currencies, being commonly used to assess the countries' competitiveness. The nominal effective exchange rate has been used by Ardagna (2004) as an indicator of the monetary stance. A negative change in this indicator corresponds to currency depreciation and therefore a monetary expansion. We also included the real effective exchange rate with the purpose of accounting for possible differences in monetary episodes identification due to price developments, which links to the arguments presented on the interest rates case.

In order to define the monetary episodes we relied on a similar strategy as Afonso (2006, 2010) and identified an episode when the absolute change in one year or the average change in two years in the different indicators was greater than 1.5 times or 1 time the panel standard deviation respectively:

$$
M E_{t}^{l}=\left\{\begin{array}{l}
1, \text { if }\left|\Delta M_{t}^{l}\right|>1,5 \sigma^{l} \\
1, \text { if }\left|\frac{\Delta M_{t}^{l}+\Delta M_{t-1}^{l}}{2}\right|>\sigma^{l} \quad l=1,2,3 . \\
0, \text { otherwise }
\end{array}\right.
$$

$M E_{t}^{l}$ denotes a monetary episode in period t according to criteria $1 ; \Delta M_{t}^{l}$ corresponds to the change of the indicator 1 in period t. For the real short term interest rate we have an absolute change while in the nominal and real effective exchange rates we used the percentage change of the respective indexes. $\sigma^{l}$ stands for the panel standard deviation of the relevant indicator.

Table II shows the monetary episodes identified according to the different indicators. $M E^{1}, M E^{2}$ and $M E^{3}$ correspond to the use of the methodology across the changes in the real short term interest rate, and the percent changes in the real and nominal effective exchange rate, respectively.

\footnotetext{
${ }^{7}$ See for instance Afonso \& Sousa (2011).
} 
One of the main highlights is that there are considerably more monetary episodes than fiscal ones. The duration of the monetary episodes also changes significantly across the different criteria. If we look at the monetary episodes based on the change in the real short term interest rate $\left(M E^{1}\right)$, it is possible to see that the expansions and contractions last 1.5 and 1.8 years on average respectively. If we consider the changes in the nominal effective exchange rates the duration of the expansions more than doubles and in the case of the contractions it also increases significantly.

Moreover, while in the fiscal episodes case there is a significant overlapping across the different criteria, in here it is much lower, with the matching being only 38,51 and 63 percent between $M E^{1}$ and $M E^{2}, M E^{1}$ and $M E^{3}$ and $M E^{2}$ and $M E^{3}$, respectively.

Also, we can see that there are episodes labelled as expansions in $M E^{1}$ that show up as contractions in $M E^{2}$ and $M E^{3}$, which further motivates the inclusion and analysis of all the different criteria.

\section{[Table II]}

\section{Empirical assessment}

\subsection{Data description}

The data consists on annual frequency time series ranging from 1970 to 2012 for private consumption, GDP, general government final consumption, social transfers, taxes, cyclically adjusted primary balance, general government debt, revenue and expenditure, taken from the AMECO database. ${ }^{8}$ We used 11 countries who belong to the EMU, ${ }^{9}$ namely Austria, Belgium, Germany, Finland, France, Greece, Ireland, Italy, Netherlands, Portugal and Spain and also Denmark, Sweden and United Kingdom, which are not in the EMU, but are geographically and politically linked to the remaining. This means that we can have a maximum of 602 observations per variable, throughout the entire panel.

The unit root tests are available on the working paper version and show that most series are stationary. For the ones that are not, since we have already computed significant changes on the original series, such that what we have are the logarithms of the real per capita values, it makes sense to include all the series in levels. Otherwise we would risk losing some

\footnotetext{
${ }^{8}$ For full description of the original series see table A1 in the Appendix.

${ }^{9}$ Originally we also had Luxembourg, which was dropped due to the lack of information on monetary data.
} 
of the intuition behind the variable relationship, thus making the model more difficult to interpret. $^{10}$

\subsection{Modelling expansionary fiscal consolidations}

The strategy for accessing the potential differences between fiscal expansions and fiscal contractions is based on Afonso (2006, 2010). It consists on estimating the variation of private consumption, using budgetary variables and dummies for assessing fiscal and monetary episodes. The core specification will be

$$
\begin{gathered}
\Delta C_{i t}=c_{i}+\lambda C_{i t-1}+\omega_{0} Y_{i t-1}+\omega_{1} \Delta Y_{i t}+\delta_{0} Y_{i t-1}^{a v}+\delta_{1} \Delta Y_{i t}^{a v}+ \\
\left(\alpha_{1} F C E_{i t-1}+\alpha_{3} \Delta F C E_{i t}+\beta_{1} T F_{i t-1}+\beta_{3} \Delta T F_{i t}+\gamma_{1} T A X_{i t-1}+\gamma_{3} \Delta T A X_{i t}\right) \times F C_{i t}^{m}+ \\
\left(\alpha_{2} F C E_{i t-1}+\alpha_{4} \Delta F C E_{i t}+\beta_{2} T F_{i t-1}+\beta_{4} \Delta T F_{i t}+\gamma_{2} T A X_{i t-1}+\gamma_{4} \Delta T A X_{i t}\right) \times\left(1-F C_{i t}^{m}\right)+\mu_{i t}
\end{gathered}
$$

where $i(i=1, \ldots, N)$ indicates the different countries, $t(t=1, \ldots, T)$ stands for the period. We also have: $C$ - private consumption; $Y$ - GDP; $Y^{a v}$ - panel's GDP average; ${ }^{11} F C E$ - general government final consumption expenditure; $T F$ - social transfers; $T A X$ - taxes. All variables displayed correspond to the natural logarithm of the real per capita values. ${ }^{12} F C^{m}$ is a dummy variable that identifies a fiscal consolidation episode, according to the three different criteria mentioned in the previous section $(m=1,2,3)$. Therefore, when $F C_{i t}^{m}$ is equal to one, there is a fiscal consolidation in period $t$, for country $i$, according to the criteria $m . c_{i}$ is an autonomous term which captures each country's individual characteristics, being the source of cross-country heterogeneity in a Fixed Effects model, which will be our estimation choice. The disturbances $\mu_{i t}$ are assumed to be independent and identically distributed across countries with zero mean and constant variance.

\footnotetext{
${ }^{10}$ Our argument follows the explanation presented in Afonso (2006, 2010).

${ }^{11}$ The original specification in Afonso $(2006,2010)$ used the OECD's GDP instead of the panel average. Nevertheless, since OECD only displays that series starting from 1995 we followed Afonso \& Jalles (2011) and used the panel average GDP.

12 For instance, in order to obtain the variable $Y$ we make the following calculations: $Y=\ln \left(\frac{G D P / D E F}{N}\right)$, where $G D P$ stands for the GDP at current prices, $D E F$ and $N$ correspond to the GDP deflator and total population, respectively.
} 


\subsubsection{Core specification outputs}

According to Greene (2012), we use the Fixed Effects (FE) estimation whenever we are interested in analysing the impact of variables that change over time. It explores the relationship between predictor and dependent variables within a country. The FE model removes the effect of time-invariant characteristics from the predictor variables so we can assess the independent variables net effect. An important assumption of the model is that time invariant characteristics are country specific and should not be correlated with other individual features. In other words, each country has unique attributes that are not the result of random variation and that do not vary across time. The source of country heterogeneity is given by the intercept $c_{i}$ in specification (1) with Fixed Effects allowing for correlation between the latter and the repressors. ${ }^{13}$

We perform redundant FE likelihood ratio tests for all estimations, with the null hypothesis being that there is no unobserved heterogeneity and so the model can be estimated by pooled OLS. If we reject this hypothesis then fixed effects is more adequate than pooled OLS, since it allows for cross country heterogeneity by permitting each one to have its own intercept value $\left(c_{i}\right){ }^{14}$

Table III presents the estimation results for specification (2) according to the different criteria for identifying fiscal consolidation episodes. Both consumption and income are statistically significant across the different specifications. The negative sign for consumption in $\mathrm{t}-1$ ( $\lambda$ ) has obviously to do with the fact that we have the lagged consumption as an independent variable, therefore increasing consumption in period $\mathrm{t}-1$ decreases its difference between $t$ and $t-1$. The short-run elasticity of private consumption to income is similar across specifications, ranging between 0.083 and 0.087 .

There is a positive statistically significant relationship between the first difference of general government final consumption expenditure $\left(\triangle F C E_{t}\right)$ and private consumption $\left(\Delta C_{t}\right)$ when we have a fiscal consolidation $\left(F C^{m}=1\right)$, across all of the estimations based on (2), with coefficients between 0.193 and 0.237 . Such relationship is in line with the traditional Keynesian effects, indicating that consumers are not behaving in a Ricardian way, since they

\footnotetext{
${ }^{13}$ In the FE estimation the intercept also works as a substitute for non-specified variables, yielding consistent estimates in the presence of correlation between the latter and the repressors, which favours the usage of this model in comparison to pooled OLS.

${ }^{14} \mathrm{We}$ report the redundant FE likelihood ratio for all estimations. In any case the no cross-country heterogeneity assumption is always rejected, meaning that the FE estimator is more adequate than pooled OLS.
} 
do not seem to anticipate the need for increased taxation in the future due to an increase in government spending today.

The previous relationship does not hold in the absence of a fiscal consolidation episode. Moreover, there is some evidence of non-Keynesian effects in the absence of fiscal consolidations $\left(F C^{m}=0\right)$ if we look at the final consumption expenditure $\left(F C E_{t-1}\right)$ and taxes $\left(T A X_{t-1}\right)$ in column 3 and across the three different estimations, respectively. The negative sign in the short-run elasticity of general government final consumption expenditure to private consumption suggests Ricardian behaviour in the absence of fiscal consolidations. Similar non-Keynesian reasoning holds for the relationship between taxes and consumption, meaning that an increase in taxes today leads to increased spending as consumers anticipate that there is no need for increased taxation in the future.

\section{[Table III]}

However the Wald coefficient statistical tests suggest that there is no significant difference between the presence and absence of fiscal consolidations concerning the short-run effects of government final consumption expenditure and taxation on private consumption (the null hypothesis: $\alpha_{3}-\alpha_{4}=0$ and $\gamma_{1}-\gamma_{2}=0$ are not rejected on the second and third specifications, respectively).

Comparing to the literature that used similar methodology, as a whole our results differ from Afonso (2006, 2010) and Afonso \& Jalles (2012), since we find no evidence of non-Keynesian effects considering general government final consumption expenditure or taxes in the presence of fiscal consolidations $\left(F C^{m}=1\right)$. However, our findings are similar for periods of no fiscal consolidation $\left(F C^{m}=0\right)$, since there is some evidence of nonKeynesian effects in this case for the mentioned budgetary variables.

\subsubsection{Fiscal consolidations and monetary expansions.}

The following specification is one of the main contributions of this paper, adding each country's monetary developments to specification (2). It will permit a breakdown of all the possible combinations between fiscal contractions and monetary expansions, thus allowing for the study of the possible differences between them. 


$$
\begin{gathered}
\Delta C_{i t}=c_{i}+\lambda C_{i t-1}+\omega_{0} Y_{i t-1}+\omega_{1} \Delta Y_{i t}+\delta_{0} Y_{i t-1}^{a v}+\delta_{1} \Delta Y_{i t}^{a v}+ \\
\left(\alpha_{10} F C E_{i t-1}+\alpha_{30} \Delta F C E_{i t}+\beta_{10} T F_{i t-1}+\beta_{30} \Delta T F_{i t}+\gamma_{10} T A X_{i t-1}+\gamma_{30} \Delta T A X_{i t}+\eta_{50} \Delta M_{i t}^{l}\right) \times F C_{i t}^{m} M X_{i t}^{l}+ \\
\left(\alpha_{20} F C E_{i t-1}+\alpha_{40} \Delta F C E_{i t}+\beta_{20} T F_{i t-1}+\beta_{40} \Delta T F_{i t}+\gamma_{20} T A X_{i t-1}+\gamma_{40} \Delta T A X_{i t}+\eta_{60} \Delta M_{i t}^{l}\right) \times\left(1-F C_{i t}^{m}\right) M X_{i t}^{l}+ \\
\left(\alpha_{11} F C E_{i t-1}+\alpha_{31} \Delta F C E_{i t}+\beta_{11} T F_{i t-1}+\beta_{31} \Delta T F_{i t}+\gamma_{11} T A X_{i t-1}+\gamma_{31} \Delta T A X_{i t}+\eta_{51} \Delta M_{i t}^{l}\right) \times F C_{i t}^{m}\left(1-M X_{i t}^{l}\right)+ \\
\left(\alpha_{21} F C E_{i t-1}+\alpha_{41} \Delta F C E_{i t}+\beta_{21} T F_{i t-1}+\beta_{41} \Delta T F_{i t}+\gamma_{21} T A X_{i t-1}+\gamma_{41} \Delta T A X_{i t}+\eta_{61} \Delta M_{i t}^{l}\right) \times\left(1-F C_{i t}^{m}\right)\left(1-M X_{i t}^{l}\right)+\mu_{i t}
\end{gathered}
$$

In addition to the repressors previously explained, $M X_{i t}^{l}$ denotes a monetary expansion in period $t(t=1, \ldots, T)$ for country $i \quad(i=1, \ldots, N)$ according to the criteria $l(l=1,2,3) . \Delta M^{l}$ corresponds to the relevant indicator used to calculate the monetary episodes on (1). We have found some evidence of non-Keynesian effects during fiscal consolidations in 5 out of the 9 possible estimations. ${ }^{15}$ Tables IV and V show some of the most relevant estimation results.

\section{[Table IV]}

\section{[Table V]}

We can see that when the fiscal consolidations are matched by a monetary expansion there is a negative and statistically significant short-term elasticity between the government final consumption expenditure and private consumption $\left(\alpha_{30}<0\right.$ in the first and second outputs and $\alpha_{10}<0$ in the third output). This doesn't hold for fiscal consolidations that are not accompanied by a monetary easing as $\alpha_{31}$ is positive and statistically significant and $\alpha_{11}$ is not statistically significant across the respective outputs. The second and third estimation results also show some evidence of non-Keynesian elasticity on taxes when there are both fiscal contractions and monetary expansions $\left(\gamma_{30}>0\right)$. Just like in the previous case, such effects seem to disappear when we have fiscal consolidations without the respective monetary easing as $\gamma_{31}$ is not statistically significant. The same pattern emerges again for social transfers on the first and third outputs $\left(\beta_{30}\right.$ is negative and statistically significant, but $\beta_{31}$ is not statistically significant). The Wald coefficient restriction tests show that the difference between these

\footnotetext{
${ }^{15}$ Notice that since we have three different criteria for fiscal and monetary developments, the assessment of their relationship within the current framework yields 9 possible estimation outputs. The other outputs are available on the working paper.
} 
coefficients is statistically significant in all cases, except for social transfers in the first output $\left(\beta_{30}-\beta_{31}=0\right.$ is not rejected at a $10 \%$ level in this case).

A possible explanation relates to liquidity restrictions, which may prevent a Ricardian behaviour, thus undermining the permanent income hypothesis. If households do have liquidity constrains, a fiscal consolidation could signal indeed a future tax decrease and a permanent income rise, which is perceived by the households, but does not materialize in a current private consumption increase due to limitations in access to credit markets. Such is summarized by Alesina \& Ardagna (1998) as "the size of the increase in private consumption [following government spending cuts] depends on the absence of liquidity-constrained consumers".

The IS-LM framework argument presented by Ardagna (2004) that the signs of the coefficients may be biased in the sense that they are capturing the monetary stance is unlikely, since we are controlling for these. Table VI summarises the robustness tests computed for specification (3).

[Table VI]

\subsection{Measuring the success of fiscal consolidations}

In this section we investigate what are the factors that may contribute to the success of fiscal consolidations. We computed dummy variables for successful fiscal adjustments in two different ways based on the literature in order to assess if our findings are robust across different criteria. The first measure $\left(S U_{t}^{1}\right)$ is based on Afonso \& Jalles (2012) who define a fiscal consolidation as being successful if the change in the cyclically adjusted primary balance $\left(\Delta b_{t}\right)$ for two consecutive years is greater than the standard deviation $(\sigma)$ of the full panel sample:

$$
S U_{t}^{1}=\left\{\begin{array}{l}
1, \text { if } \sum_{i=0}^{1} \Delta b_{t+i}>\sigma \\
0, \text { otherwise }
\end{array} .\right.
$$

We have also included a measure computed by Alesina \& Ardagna (2013) which is based on the level of debt as a percentage of GDP. A fiscal consolidation is successful if the 
debt-to-GDP ratio two years after the end of the fiscal adjustment $\left(D e b t_{t+2}\right)$ is lower than the debt-to-GDP ratio in the last year of the adjustment $\left(\right.$ Debt $\left._{t}\right)$ :

$$
S U_{t}^{2}=\left\{\begin{array}{l}
1, \text { if } \text { Debt }_{t+2}<\text { Debt }_{t} \\
0, \text { otherwise }
\end{array}\right.
$$

Table VII shows the successful fiscal episodes for the different countries.

\section{[Table VII]}

The identification of the leading policy option for the fiscal consolidation - either expenditure or revenue based - is also assessed through dummy variables. Therefore, a fiscal consolidation on period $t$ is defined as being expenditure based $\left(E X P_{t}\right)$ if the change in the total expenditure of the general government as a percentage of GDP in that period $\left(\Delta \exp _{t}\right)$ accounts for a proportion greater than $\lambda$ of the change in the cyclically adjusted primary balance $\left(\Delta b_{t}\right)$

$$
\operatorname{EXP}_{t}=\left\{\begin{array}{l}
1, i f \frac{\Delta \exp _{t}}{\Delta b_{t}}>\lambda \\
0, \text { otherwise }
\end{array} .\right.
$$

Following Afonso \& Jalles (2012) we computed the composition of the adjustment for three different thresholds, so that $\lambda$ assumes the values of $1 / 2,2 / 3$ and $3 / 4$. A similar process was conducted for the revenue based consolidations. we estimated a probit model based on Afonso \& Jalles (2012) in order to assess if the reported differences between the expenditure and revenue based consolidations are statistically relevant and impinge on the success of the fiscal adjustments:

$$
\operatorname{Pr}_{i}\left(S U=1 \mid Z_{i}\right)=E\left[S U=1 \mid Z_{i}\right]=\Phi\left(Z_{i}\right)
$$

where $E\left[S U=1 \mid Z_{i}\right]$ is the conditional expectation of the success of the fiscal consolidation, given $Z_{i}$ and $S U$ refers to the dummy variables defined in (4) and (5). $Z_{i}$ is defined as follows: 


$$
Z_{i}=\delta_{1}+\delta_{2} D_{i}+\delta_{3} \Delta b_{i}+\delta_{4} E X P_{i}+\delta_{5} M X_{i}
$$

$D_{i}$ is the duration of the fiscal consolidation, $\Delta b_{i}$ refers to the change in the cyclically adjusted primary balance, which accounts for the size of the consolidation. $E X P_{i}$ was defined in (6) as a dummy variable that accounts for expenditure based consolidations, according to different thresholds, while the same was done on the revenue side.

We also included $M X_{i}$ which refers to the dummy variable used to identify the monetary expansions computed earlier, according to (1). The motivation behind this addition has to do with an issue raised in the recent literature, which has to do with the possible influence of the monetary expansions in determining the success of fiscal consolidations.

For instance, Devries et al. (2011) suggest that expenditure based consolidations where more successful because they were complemented by monetary expansions, in the form of strong currency devaluations. Alesina et al. (2012) mention the importance of accompanying monetary policy in determining the possible heterogeneous effects of expenditure based and revenue based consolidations. Alesina \& Ardagna (2013) also account for the possible role of the monetary policy in differentiating the effects of expenditure versus revenue based adjustments.

Table VIII shows the results for the success measure constructed by Afonso \& Jalles (2012), based on $F C^{2} .{ }^{16}$ The results for the other criteria used to compute fiscal consolidations are available on request.

We can see that according to the measure first computed by Afonso \& Jalles (2012) the success of the fiscal consolidations seems to be enhanced if based on expenditure cuts. On the other hand, we find no statistically significant results for the revenue based consolidations. Moreover, both the duration and size of the consolidations seem to play a significant role: longer and stronger consolidations appear to contribute positively for the success of the fiscal consolidations. These results hold for all of the reported thresholds in $F C^{2}$ and $F C^{3}$. In the $F C^{1}$ case we find statistically significant results only for the size of the consolidations. ${ }^{17}$ Concerning the role of the monetary policy, we find no statistically significant results. ${ }^{18}$

\footnotetext{
16 Some observations were excluded due to the fact that they occur in the last years of the sample and therefore we cannot assess if they were successful according to either (4) or (5).

${ }^{17}$ Results for the $F C^{1}$ and $F C^{3}$ cases are available on the working paper.

${ }^{18}$ Results for $M X^{3}$ are available on request and do not alter the overall findings. We could not compute the estimations for $M X^{1}$ since it perfectly predicts the success of the fiscal consolidations.
} 


\section{[Table VIII]}

Table IX shows the results for the success criterion $S U^{2}$, based on $F C^{1}$. The results for $F C^{2}$ and $F C^{3}$ are available on the working paper version. The results are similar to the ones found in the $S U^{1}$ case, concerning the role of the duration and of the expenditure based adjustments in the success of the fiscal consolidations. Moreover, we have found some evidence that the revenue based consolidations have a negative impact on the success of the adjustment. On the other hand, contrary to the findings for $S U^{1}$, the size of the consolidation has a negative impact on the success of the consolidation, thus not being robust across the different criteria.

\section{[Table IX]}

Regarding the role of the monetary policy in the $F C^{2}$ case (available on the working paper) there is some evidence that real currency devaluations $\left(M X^{2}\right)$ contribute negatively to the success of the adjustments. However, since we cannot check the robustness of these results with a monetary expansion based on the real short term interest rate $\left(M X^{1}\right)$ because of the same problem reported earlier for $S U^{1}$, we would not extract a clear conclusion here. Furthermore, the fact that $M X^{1}$ perfectly predicts the success of the fiscal consolidations could actually lead to opposite conclusions to the ones found for either $M X^{2}$ or $M X^{3}$. So we would rather say that the impact of the monetary easing in the success of the fiscal consolidations is not clear.

To sum up, the most robust findings for the success of the fiscal consolidation were obtained for the impact of the duration and of the expenditure based consolidations. Both contribute positively for the success of the fiscal adjustments, across the different criteria. In addition, there is some evidence that fiscal consolidations based on tax raises have a negative impact on the success of the fiscal consolidations.

The size of the consolidation gives us mixed evidence: it seems to contribute positively for the success of fiscal consolidations based on $S U^{1}$, which is consistent with Afonso \& Jalles (2012), but the opposite is verified for $S U^{2}$. The role of the monetary policy is also unclear. Table $\mathrm{X}$ shows the robustness test for specification (8)

[Table X] 


\section{Conclusions}

This paper aimed at providing new insights about expansionary fiscal consolidations in the EMU, by incorporating monetary developments on specifications previously used on empirical research. The Fixed Effects panel estimations conducted for 14 European Union countries show no evidence of non-Keynesian effects during fiscal consolidations, when the monetary policy developments are not considered. Nevertheless, there is some evidence of non-Keynesian effects in the absence of fiscal consolidations.

On the other hand, when the baseline specification is extended in order to accommodate the monetary developments, there is some evidence of non-Keynesian effects during fiscal consolidations. When fiscal consolidation episodes are matched by a monetary expansion, there is a shift on the standard Keynesian impact of government final consumption expenditure and taxation on private consumption.

Overall, when fiscal consolidations are not matched by a monetary expansion, the nonKeynesian effects captured earlier disappear. The size of the increase in private consumption due to a fiscal consolidation depends on the absence of liquidity-constrained households, which may prevent Ricardian behaviour, thus undermining the permanent income hypothesis of consumption smoothing. A monetary expansion provides the necessary liquidity increase during fiscal consolidations that allows individuals to smooth their consumption.

Attending on the success of the fiscal consolidations, the probit estimations show evidence which suggests that longer lasting adjustment periods seem to contribute positively for their success. Even so, the role of the size of the consolidations in this regard is unclear.

Additionally, expenditure based consolidations are more likely to be successful than the ones based on tax raises. These findings are more robust for the expenditure based consolidations.

The overall role of the monetary policy in the success of the fiscal consolidations is unclear. On the one hand, we have some (although scarce) evidence that monetary expansions based on real currency devaluations contribute negatively for the success of fiscal consolidations. On the other hand, we cannot perform probit estimations for monetary expansions based on the real interest rate since those near to perfectly predict the success of fiscal consolidations, which means that in almost every case a monetary expansion based on the real interest rate is associated with a successful fiscal adjustment.

Future research may include the assessment of the factors that may influence the occurrence of expansionary episodes, through a binary choice model and also the usage of the so called policy-action based approach for identifying fiscal episodes. 


\section{References}

Afonso, A. (2006). Expansionary fiscal consolidations in Europe: new evidence. European Central Bank, Woking Paper Series No. 675, September.

Afonso, A. (2010). Expansionary fiscal consolidations in Europe: new evidence. Applied Economics Letters 17 (2), 105-109.

Afonso, A. and Jalles, J. (2014). Assessing fiscal episodes. Economic Modelling, 37, 255-270.

Afonso, A. and Jalles, J. (2012). Measuring the success of fiscal consolidations. Applied Financial Economics 22 (13), 1053-1061.

Afonso, A. and Sousa, R. (2011). The macroeconomic effects of fiscal policy in Portugal: a Bayesian SVAR analysis. Portuguese Economic Journal 10 (1), 61-82.

Alesina, A. and Ardagna, S. (1998). Tales of Fiscal Adjustment. Economic Policy 27 (13), 487-545.

Alesina, A. and Ardagna, S. (2013). The Design of Fiscal Adjustments. In: Brown, J. (Ed.) NBER book series Tax Policy and the Economy (27), 19-67.

Alesina, A. and Perotti, R. (1997). Fiscal adjustments in OECD countries: compostion and macroeconomic effects. International Monetary Fund Staff Papers 44, 210-248.

Alesina, A., Favero, C. and Giavazzi, F. (2012). The output effects of fiscal Adjustments. NBER Working Paper, no 18336.

Ardagna, S. (2004). Fiscal Stabilizations: When do they Work and Why. European Economic Review 48 (5) 1047-1074.

Barro, R. (1974). Are Government Bonds Net Wealth? In: Journal of Political Economy 87, $940-971$.

Bertola, G. and Drazen, A. (1993). Trigger Points and Budget Cuts: Explaining the Effects of Fiscal Austerity. American Economic Review 83 (1), 11-26.

Blanchard, O. (1990). Comment, on Giavazzi and Pagano (1990). In Blanchard, O., Fischer, S. (Eds) NBER Macroeconomics Annual (1990), 111-116.

Devries, P., Guajardo, J., Leigh, D. and Pescatori, A. (2011). An Action-based Analysis of Fiscal Consolidations in OECD Countries. IMF Working Paper Series no. 11/128.

Giavazzi, F. and Pagano, M. (1990). Can Severe Fiscal Contractions be Expansionary? Tales of Two Small European Countries. In Blanchard, O. and Fisher, S. (Eds.). NBER Macroeconomics Annual (1990), MIT Press.

Giavazzi, F. and Pagano, M. (1996). Non-keynesian Effects of Fiscal Policy Changes: International Evidence and the Swedish Experience. Swedish Economic Policy Review 3 (1), $67-103$. 
Giavazzi, F., Jappelli, T. and Pagano, M. (2000). Searching for non-linear effects of fiscal policy: evidence from industrial and developing countries. European Economic Review 44 (7), 1259-1289.

Giudice, G., Turrini, A. and in't Veld, J. (2004). Non-Keynesian fiscal consolidation in the EU? Ex post evidence and ex ante analysis. CEPR Discussion Paper 4388.

Hjelm, G. (2002). Is private consumption higher (lower during periods of fiscal contractions (expansions)? Journal of Macroeconomics 24, 17-39.

Hellwig, M. and Neumann, M. (1987). Economic Policy in Germany: Was there a Turnaround? Economic Policy 2 (4), 103-145.

Perotti, R. (1999). Fiscal Policy in Good Times and Bad. Quarterly Journal of Economics 144 (4), 1399-1436.

Perotti R. (2012). The Austerity Myth: Growth without Pain?. In A. Alesina and F. Giavazzi (eds.) Fiscal Policy After the Great Recession (2013) University of Chicago Press and NBER.

Prammer, D. (2004). Expansionary Fiscal Consolidations? An Appraisal of the Literature on Non-Keynesian Effects of Fiscal Policy and a Case Study for Austria. Monetary Policy and the Economy 3, 34-52.

Sutherland, A. (1997). Fiscal Crises and Aggregate Demand: Can High Public Debt Reverse the Effects of Fiscal Policy? Journal of Public Economics 65 (2), 147-162.

Greene, William H. (2012). Econometric analysis, $7^{\text {th }}$ ed. New Jersey: Prentice Hall. 
Table I - Identification of the fiscal episodes according to the different criteria (1970-2012)

\begin{tabular}{|c|c|c|c|c|c|c|}
\hline \multirow[b]{2}{*}{ Country } & \multicolumn{2}{|c|}{$F E^{I}$} & \multicolumn{2}{|c|}{$F E^{2}$} & \multicolumn{2}{|c|}{$F E^{3}$} \\
\hline & Expansions & Contractions & Expansions & Contractions & Expansions & Contractions \\
\hline Austria & 04 & 97 & 04 & $84,97,01,05$ & 04 & $84,97,01,05$ \\
\hline Belgium & $81,05,09$ & $82-87$ & $81,05,09$ & $82-85,06$ & $81,05,09$ & $82,84-85,06$ \\
\hline Denmark & $\begin{array}{c}75-76, \\
90-91\end{array}$ & $83-87$ & $75,82,90$ & $83-86$ & $75,82,90$ & $83-86$ \\
\hline Finland & $\begin{array}{l}79-80,83, \\
91-93,10\end{array}$ & $\begin{array}{c}76-77 \\
97-98,00-01\end{array}$ & $\begin{array}{c}78,87,91 \\
09\end{array}$ & $\begin{array}{c}76-77,81, \\
88,96-97, \\
00-01 \\
\end{array}$ & $\begin{array}{c}78,87,91-92 \\
10\end{array}$ & $76,88,96,00$ \\
\hline France & & & 09 & & 09 & \\
\hline Germany & $\begin{array}{c}75,91,95 \\
01-02\end{array}$ & $96-99,12$ & $\begin{array}{l}75,90-91, \\
95,01,10\end{array}$ & $\begin{array}{c}96-97,00, \\
11-12\end{array}$ & $\begin{array}{c}75,90-91,95 \\
01-02,10\end{array}$ & $96-97,00,11$ \\
\hline Greece & $04,08-09$ & $\begin{array}{c}92-94,96 \\
10-12\end{array}$ & $\begin{array}{c}89,95, \\
08-09\end{array}$ & $\begin{array}{c}91-92,94, \\
10-12\end{array}$ & $89,95,08-09$ & $\begin{array}{c}91-92,94,10- \\
12\end{array}$ \\
\hline Ireland & $\begin{array}{r}01-02, \\
07-11\end{array}$ & $88,11-12$ & $\begin{array}{c}95,01, \\
07-10\end{array}$ & $88,11-12$ & $\begin{array}{c}95,01-02, \\
07-10\end{array}$ & $88,11-12$ \\
\hline Italy & & $83,92-94,12$ & 81,01 & $\begin{array}{c}82-83, \\
92-93,12 \\
\end{array}$ & 81,01 & $\begin{array}{c}82-83,92-93 \\
12\end{array}$ \\
\hline Netherlands & $02,09-10$ & 91,93 & 01,09 & $91,93,96$ & 01,09 & $91,93,96$ \\
\hline Portugal & $\begin{array}{c}78-80,94 \\
09-10\end{array}$ & $83-84,11-12$ & $\begin{array}{l}78-79,85 \\
93,05,09\end{array}$ & $\begin{array}{c}83-84,86 \\
88,92,11-12\end{array}$ & $\begin{array}{c}78,85,93 \\
05,09-10\end{array}$ & $\begin{array}{c}83,86,88,92, \\
11-12\end{array}$ \\
\hline Spain & $08-11$ & & 08-09 & & 08-09 & \\
\hline Sweden & $02-03$ & $96-99$ & 02 & $96-97$ & 02 & $96-97$ \\
\hline $\begin{array}{c}\text { United } \\
\text { Kingdom }\end{array}$ & $\begin{array}{c}\text { 91-93, } \\
01-04,09\end{array}$ & $97-00,11-12$ & $\begin{array}{c}90,92, \\
01-02,09\end{array}$ & $\begin{array}{c}97-98,00, \\
11-12\end{array}$ & $\begin{array}{c}90,92-93, \\
01-03,09\end{array}$ & 00,11 \\
\hline $\begin{array}{c}\text { \# Years } \\
\text { with } \\
\text { episodes }\end{array}$ & 53 & 55 & 62 & 57 & 51 & 46 \\
\hline $\begin{array}{l}\text { Average } \\
\text { duration of } \\
\text { episodes } \\
\text { (years) }\end{array}$ & 1.89 & 2.39 & 1.63 & 1.63 & 1.34 & 1.35 \\
\hline
\end{tabular}

Source: author's computations. Notes: $F E^{l}$ - Measure based on Giavazzi \& Pagano (1996); $F E^{2}-$ Measure based on Alesina \& Ardagna (1998); $F E^{3}$ - Measure based on Afonso (2006, 2010). 
Table II - Identification of the monetary episodes according to the different criteria (1970-2012)

\begin{tabular}{|c|c|c|c|c|c|c|}
\hline & \multicolumn{2}{|c|}{$M E^{1}$} & \multicolumn{2}{|c|}{$M E^{2}$} & \multicolumn{2}{|c|}{$M E^{3}$} \\
\hline Country & Expansions & Contractions & Expansions & Contractions & Expansions & Contractions \\
\hline Austria & $\begin{array}{c}72,83,94 \\
09-10\end{array}$ & $\begin{array}{c}77,80-81 \\
89-90\end{array}$ & $97-98,00$ & $\begin{array}{l}77,80,87 \\
93,95,04\end{array}$ & & $\begin{array}{c}73-80,83,86- \\
88,93,95\end{array}$ \\
\hline Belgium & $\begin{array}{c}72,75, \\
82-83, \\
93-94,10\end{array}$ & $\begin{array}{c}\text { 76-77, 79-81, } \\
90-91\end{array}$ & $\begin{array}{c}81-83, \\
97-98,00\end{array}$ & $\begin{array}{c}77,79,86-87 \\
95,03-04\end{array}$ & $81-83,97$ & $\begin{array}{c}77-78, \\
86-87,91,95, \\
03-04\end{array}$ \\
\hline Denmark & $\begin{array}{c}73,81, \\
94-97,10\end{array}$ & $\begin{array}{c}\text { 76-78, 90-91, } \\
93,07,11\end{array}$ & $80-82,00$ & $\begin{array}{l}79,86-87 \\
03-04,09\end{array}$ & $80-82,00$ & $\begin{array}{c}\text { 73-74, 76, 86- } \\
87, \\
90-91,93,95, \\
03-04\end{array}$ \\
\hline Finland & $\begin{array}{c}71-74,88, \\
93-95,98, \\
12 \\
\end{array}$ & $\begin{array}{c}75-76,80, \\
83-84,89-92\end{array}$ & $\begin{array}{c}72,78-79 \\
92-94,97 \\
00,11 \\
\end{array}$ & $\begin{array}{c}74-76,80-82, \\
85,89-90, \\
95-96,03-04\end{array}$ & $\begin{array}{c}72-73, \\
78-79,92-93,97, \\
00\end{array}$ & $\begin{array}{c}81,89-90,94- \\
96,03-04\end{array}$ \\
\hline France & $\begin{array}{c}72,75-76 \\
94,97\end{array}$ & $74,77,81,90$ & $\begin{array}{c}82-84, \\
97-98,00- \\
01 \\
\end{array}$ & $86-87,03-04$ & $\begin{array}{c}77-78, \\
81-84,00\end{array}$ & $\begin{array}{c}73,75-76,86- \\
87,90,93-96, \\
03-04\end{array}$ \\
\hline Germany & $\begin{array}{c}75,82-83 \\
86,93,02 \\
09-10\end{array}$ & $73,80-81,90$ & $\begin{array}{l}81-82,85 \\
89,97-98, \\
00-01,11\end{array}$ & $\begin{array}{c}\text { 79, 87, 93-95, } \\
03-04\end{array}$ & 97,00 & $\begin{array}{c}72-80,83-84, \\
86-88,93-96, \\
03-04\end{array}$ \\
\hline Greece & $\begin{array}{l}82,90,95- \\
96,00-03\end{array}$ & $\begin{array}{c}86,89,92-94, \\
98\end{array}$ & $\begin{array}{l}\text { 83-86, 00- } \\
01\end{array}$ & $\begin{array}{c}82,88,90-91, \\
95-96,03-04, \\
08\end{array}$ & $72-95$ & 03-04 \\
\hline Ireland & $\begin{array}{c}75-76,81, \\
88-89, \\
92-94, \\
98-99,10- \\
12\end{array}$ & $\begin{array}{c}74,77-79, \\
83-85,90-91 \\
07-09\end{array}$ & $\begin{array}{l}88-89,93- \\
94,99-00 \\
10-12\end{array}$ & $\begin{array}{c}\text { 79-80, 82-83, } \\
\text { 86-87, 02-04, } \\
\quad 07-08\end{array}$ & $\begin{array}{c}73-77, \\
81-82,84,99- \\
2000\end{array}$ & $\begin{array}{c}86,90-91,03- \\
04,08\end{array}$ \\
\hline Italy & $\begin{array}{c}73-74,94 \\
99,09\end{array}$ & $76,81-85,92$ & $93-95,00$ & $\begin{array}{c}\text { 83-84, 86-87, } \\
90-91,96-97, \\
03-04\end{array}$ & $\begin{array}{c}73-85 \\
93-95,00\end{array}$ & $\begin{array}{c}87,96-97,03- \\
04\end{array}$ \\
\hline Netherlands & $\begin{array}{c}\text { 71-72, } \\
94-95,10\end{array}$ & $\begin{array}{c}73-74,78-80 \\
90,07\end{array}$ & $\begin{array}{l}81,84-85 \\
89,97,00\end{array}$ & $\begin{array}{c}77,79,87, \\
95,02-04\end{array}$ & 97 & $\begin{array}{c}74-78,83,86- \\
88,93-95\end{array}$ \\
\hline Portugal & $\begin{array}{c}73-75,80 \\
83,88,94- \\
95,98,10\end{array}$ & $\begin{array}{c}76-79,81-82, \\
85,87,90-91, \\
08\end{array}$ & $\begin{array}{l}77-80,83- \\
84\end{array}$ & $\begin{array}{c}\text { 81-82, 89-93, } \\
02-04\end{array}$ & $76-89,94$ & \\
\hline Spain & $\begin{array}{c}84-86,88 \\
95,99 \\
\end{array}$ & $\begin{array}{c}78-81,83, \\
87-88,07-08\end{array}$ & $\begin{array}{l}\text { 82-84, 93- } \\
94\end{array}$ & $\begin{array}{c}85-91,02-03 \\
08\end{array}$ & $\begin{array}{c}76-78, \\
81-84,93-94\end{array}$ & $\begin{array}{c}74,79 \\
89-91,03-04\end{array}$ \\
\hline Sweden & $\begin{array}{l}\text { 86-87, 93- } \\
\quad 94\end{array}$ & $85,92-93$ & $\begin{array}{c}78,82-84, \\
93-94, \\
98-02,09\end{array}$ & $\begin{array}{c}79-80,85, \\
89-91,96, \\
03-04,10-12\end{array}$ & $\begin{array}{c}78-79,82-84, \\
93-94,01-02,09\end{array}$ & $\begin{array}{c}76,96-97,03- \\
04,10-12\end{array}$ \\
\hline $\begin{array}{l}\text { United } \\
\text { Kingdom }\end{array}$ & $\begin{array}{l}74-75,88 \\
02,09-10\end{array}$ & $\begin{array}{c}73,76-77, \\
81-82,90,98\end{array}$ & $\begin{array}{c}83-84, \\
86-87, \\
93-94,08- \\
10\end{array}$ & $\begin{array}{c}80-81,88-89 \\
91,97-99,05 \\
07,11-12\end{array}$ & $\begin{array}{c}73-77, \\
83-84,87,93-94 \\
08-10\end{array}$ & $\begin{array}{c}79-81,88,97- \\
99\end{array}$ \\
\hline $\begin{array}{c}\text { \# Years } \\
\text { with } \\
\text { episodes }\end{array}$ & 96 & 92 & 95 & 124 & 124 & 122 \\
\hline $\begin{array}{l}\text { Average } \\
\text { duration of } \\
\text { episodes } \\
\text { (years) }\end{array}$ & 1.55 & 1.80 & 1.98 & 1.85 & 3.26 & 2.22 \\
\hline
\end{tabular}

Source: author's computations. Notes: $M E^{l}$ - Measure based on the changes in the real short term interest rate; $M E^{2}$ - Measure based on changes in the real effective exchange rate; $M E^{3}$ - Measure based on the changes in the nominal effective exchange rate. 
Table III - Fixed Effects estimation results for specification (2)

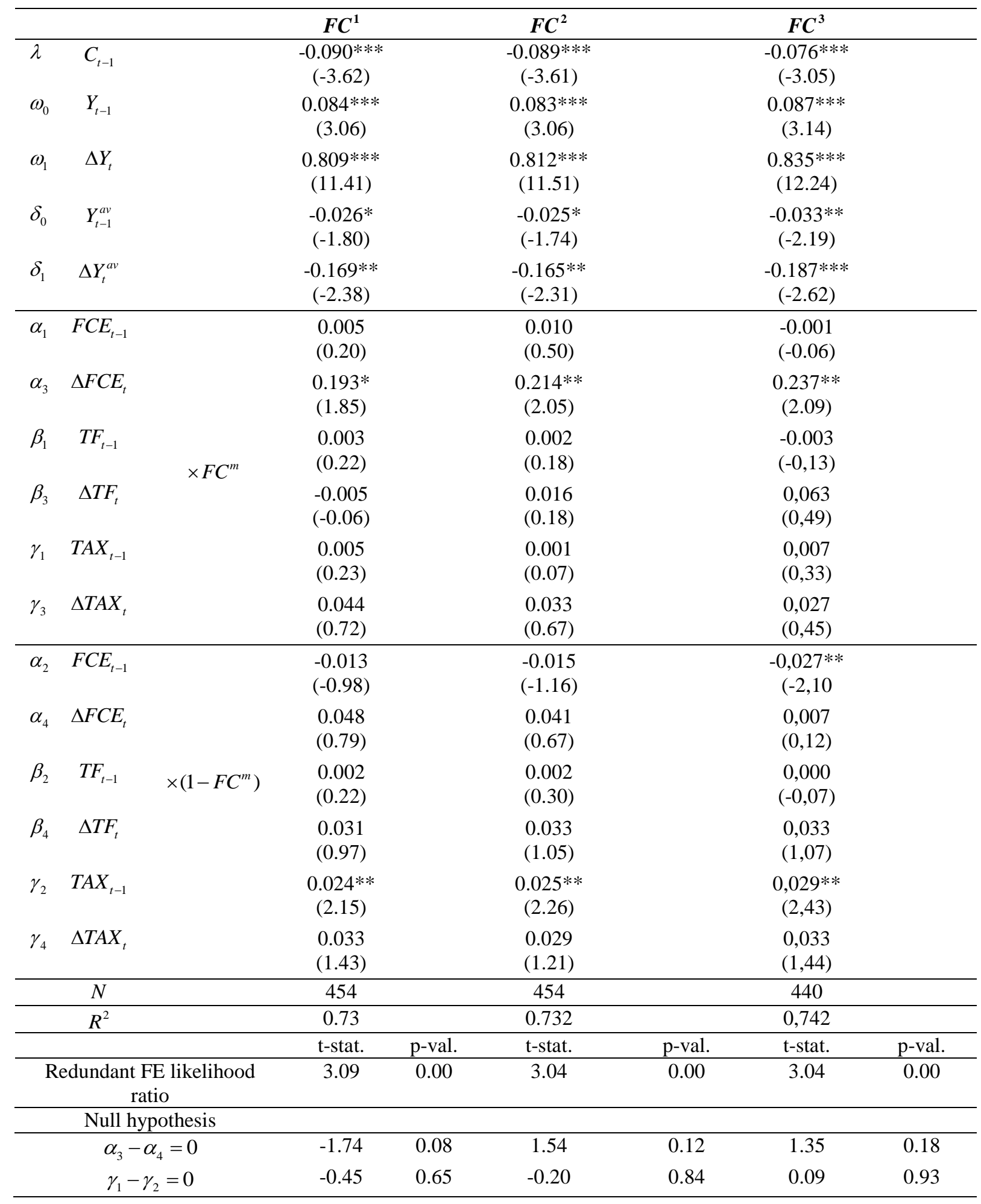

Notes: Used robust heteroskedastic-consistent standard errors. The t-statistics are in parentheses. *, ** and *** denotes statistically significant at a 10,5 and 1 percent level, respectively. $F C^{l}$ - Measure based on Giavazzi \& Pagano (1996); $F C^{2}$ - Measure based on Alesina \& Ardagna (1998); FC $C^{3}$ - Measure based on Afonso (2006, 2010). 
Table IV - Fixed Effects estimation for specification (3): $1^{\text {st }}$ output

\begin{tabular}{|c|c|c|c|c|c|}
\hline & & & $F C^{1}, M X^{3}$ & $F C^{2}, M X^{1}$ & $F C^{3}, M X^{1}$ \\
\hline$\lambda$ & $C_{t-1}$ & & $\begin{array}{c}-0.096 * * * \\
(-3.80)\end{array}$ & $\begin{array}{c}-0.097 * * * \\
(-4.05)\end{array}$ & $\begin{array}{c}-0.097 * * * \\
(-4.10)\end{array}$ \\
\hline$\omega_{0}$ & $Y_{t-1}$ & & $\begin{array}{c}0.093 * * * \\
(3.25)\end{array}$ & $\begin{array}{c}0.099 * * * \\
(3.64)\end{array}$ & $\begin{array}{c}0.102 * * * \\
(3.82)\end{array}$ \\
\hline$\omega_{1}$ & $\Delta Y_{t}$ & & $\begin{array}{c}0.803 * * * \\
(10.93)\end{array}$ & $\begin{array}{c}0.799 * * * \\
(11.14)\end{array}$ & $\begin{array}{c}0.789 * * * \\
(11.17)\end{array}$ \\
\hline$\delta_{0}$ & $Y_{t-1}^{a v}$ & & $\begin{array}{l}-0.019 \\
(-1.22)\end{array}$ & $\begin{array}{c}-0.029 * * \\
(-2.06)\end{array}$ & $\begin{array}{c}-0.0294 * * \\
(-2.06)\end{array}$ \\
\hline$\delta_{1}$ & $\Delta Y_{t}^{a v}$ & & $\begin{array}{c}-0.181 * * \\
(-2.53)\end{array}$ & $\begin{array}{c}-0.155^{* *} \\
(-2.22)\end{array}$ & $\begin{array}{c}-0.145^{* *} \\
(-2.08)\end{array}$ \\
\hline$\alpha_{10}$ & $F C E_{t-1}$ & & $\begin{array}{l}0.050 \\
(1.40)\end{array}$ & $\begin{array}{l}0.200 \\
(1.33)\end{array}$ & $\begin{array}{c}-0.840 * * * \\
(-14.24)\end{array}$ \\
\hline$\alpha_{30}$ & $\triangle F C E_{t}$ & & $\begin{array}{c}-0.213 * * * \\
(-3.58)\end{array}$ & $\begin{array}{c}-0.369 * \\
(-1.72)\end{array}$ & $\begin{array}{l}-0.039 \\
(-0.30)\end{array}$ \\
\hline$\beta_{10}$ & $T F_{t-1}$ & $\times F C^{m}$ & $\begin{array}{l}0.010 \\
(0.69)\end{array}$ & $\begin{array}{l}0.026 \\
(0.84)\end{array}$ & $\begin{array}{c}1.293 * * * \\
(21.38)\end{array}$ \\
\hline$\beta_{30}$ & $\Delta T F_{t}$ & $\times M X^{l}$ & $\begin{array}{c}-0.130 * \\
(-1.83)\end{array}$ & $\begin{array}{l}0.034 \\
(0.12)\end{array}$ & $\begin{array}{c}-11.42 * * * \\
(-19.53)\end{array}$ \\
\hline$\gamma_{10}$ & $T A X_{t-1}$ & & $\begin{array}{c}-0.051 * * \\
(-2.06)\end{array}$ & $\begin{array}{c}-0.206 * \\
(-1.71)\end{array}$ & $\begin{array}{c}-0.552 * * * \\
(-9.29)\end{array}$ \\
\hline$\gamma_{30}$ & $\triangle T A X_{t}$ & & $\begin{array}{c}-0.132 * * * \\
(-3.07)\end{array}$ & $\begin{array}{c}0.484 * * * \\
(4.55)\end{array}$ & $\begin{array}{c}2.694 * * * \\
(17.32)\end{array}$ \\
\hline$\eta_{50}$ & $\Delta M_{t}^{l}$ & & $\begin{array}{c}0.096 * * \\
(2.08)\end{array}$ & $\begin{array}{l}0.003 \\
(0.49)\end{array}$ & $\begin{array}{c}-0.215 * * * \\
(-20.12)\end{array}$ \\
\hline
\end{tabular}


Table V - Fixed Effects estimation for specification (3): $1^{\text {st }}$ output (cont.)

\begin{tabular}{|c|c|c|c|c|c|c|c|c|}
\hline & & & $F C^{1}, M X^{3}$ & & $F C^{2}, M X^{1}$ & & $F C^{3}, M X^{1}$ & \\
\hline$\alpha_{20}$ & $F C E_{t-1}$ & \multirow{7}{*}{$\begin{array}{c}\times\left(1-F C^{m}\right) \\
\times M X^{l}\end{array}$} & $\begin{array}{l}-0.005 \\
(-0.24)\end{array}$ & & $\begin{array}{c}-0.035 * * \\
(-2.15)\end{array}$ & & $\begin{array}{c}-0.038 * * \\
(-2.39)\end{array}$ & \\
\hline$\alpha_{40}$ & $\triangle F C E_{t}$ & & $\begin{array}{c}0.270 * * \\
(2.51)\end{array}$ & & $\begin{array}{l}0.010 \\
(0.09)\end{array}$ & & $\begin{array}{l}0.010 \\
(0.09)\end{array}$ & \\
\hline$\beta_{20}$ & $T F_{t-1}$ & & $\begin{array}{l}0.014 \\
(1.21)\end{array}$ & & $\begin{array}{l}-0.018 \\
(-1.57)\end{array}$ & & $\begin{array}{l}-0.018 \\
(-1.52)\end{array}$ & \\
\hline$\beta_{40}$ & $\Delta T F_{t}$ & & $\begin{array}{l}-0.043 \\
(-0.91)\end{array}$ & & $\begin{array}{l}-0.028 \\
(-0.58)\end{array}$ & & $\begin{array}{l}-0.029 \\
(-0.59)\end{array}$ & \\
\hline$\gamma_{20}$ & $T A X_{t-1}$ & & $\begin{array}{l}-0.007 \\
(-0.47)\end{array}$ & & $\begin{array}{c}0.056^{* * *} \\
(3.74)\end{array}$ & & $\begin{array}{c}0.055^{* * *} * \\
(3.67)\end{array}$ & \\
\hline$\gamma_{40}$ & $\Delta T A X_{t}$ & & $\begin{array}{l}-0.027 \\
(-0.52)\end{array}$ & & $\begin{array}{l}-0.002 \\
(-0.04)\end{array}$ & & $\begin{array}{l}-0.004 \\
(-0.08)\end{array}$ & \\
\hline$\eta_{60}$ & $\Delta M_{t}^{l}$ & & $\begin{array}{l}0.025 \\
(0.52)\end{array}$ & & $\begin{array}{l}-0.000 \\
(-0.55)\end{array}$ & & $\begin{array}{l}-0.001 \\
(-0.48)\end{array}$ & \\
\hline$\alpha_{11}$ & $F C E_{t-1}$ & \multirow{7}{*}{$\begin{array}{c}\times F C^{m} \\
\times\left(1-M X^{l}\right)\end{array}$} & $\begin{array}{l}0.011 \\
(0.42)\end{array}$ & & $\begin{array}{l}0.005 \\
(0.22)\end{array}$ & & $\begin{array}{l}0.002 \\
(0.07)\end{array}$ & \\
\hline$\alpha_{31}$ & $\triangle F C E_{t}$ & & $\begin{array}{c}0.260 * * \\
(2.36)\end{array}$ & & $\begin{array}{c}0.310 * * * \\
(3.57)\end{array}$ & & $\begin{array}{c}0.405^{* * *} \\
(5.13)\end{array}$ & \\
\hline$\beta_{11}$ & $T F_{t-1}$ & & $\begin{array}{l}-0.007 \\
(-0.40)\end{array}$ & & $\begin{array}{l}0.003 \\
(0.35)\end{array}$ & & $\begin{array}{l}-0.005 \\
(-0.37)\end{array}$ & \\
\hline$\beta_{31}$ & $\Delta T F_{t}$ & & $\begin{array}{l}-0.093 \\
(-1.01)\end{array}$ & & $\begin{array}{l}-0.025 \\
(-0.31)\end{array}$ & & $\begin{array}{l}-0.063 \\
(-0.59)\end{array}$ & \\
\hline$\gamma_{11}$ & $T A X_{t-1}$ & & $\begin{array}{l}-0.006 \\
(-0.28)\end{array}$ & & $\begin{array}{l}0.002 \\
(0.09)\end{array}$ & & $\begin{array}{l}0.008 \\
(0.40)\end{array}$ & \\
\hline$\gamma_{31}$ & $\Delta T A X_{t}$ & & $\begin{array}{l}0.120 \\
(1.58)\end{array}$ & & $\begin{array}{l}-0.017 \\
(-0.36)\end{array}$ & & $\begin{array}{l}-0.051 \\
(-0.85)\end{array}$ & \\
\hline$\eta_{51}$ & $\Delta M_{t}^{l}$ & & $\begin{array}{l}0.044 \\
(0.84) \\
\end{array}$ & & $\begin{array}{l}0.001 \\
(1.31) \\
\end{array}$ & & $\begin{array}{l}0.002 \\
(1.78) \\
\end{array}$ & \\
\hline$\alpha_{21}$ & $F C E_{t-1}$ & \multirow{7}{*}{$\begin{array}{l}\times\left(1-F C^{m}\right) \\
\times\left(1-M X^{l}\right)\end{array}$} & $\begin{array}{l}-0.021 \\
(-1.42)\end{array}$ & & $\begin{array}{l}-0.015 \\
(-0.98)\end{array}$ & & $\begin{array}{l}-0.017 \\
(-1.17)\end{array}$ & \\
\hline$\alpha_{41}$ & $\triangle F C E_{t}$ & & $\begin{array}{l}0.006 \\
(0.10)\end{array}$ & & $\begin{array}{l}0.038 \\
(0.55)\end{array}$ & & $\begin{array}{l}0.029 \\
(0.42)\end{array}$ & \\
\hline$\beta_{21}$ & $T F_{t-1}$ & & $\begin{array}{l}0.003 \\
(0.45)\end{array}$ & & $\begin{array}{l}0.005 \\
(0.61)\end{array}$ & & $\begin{array}{l}0.005 \\
(0.70)\end{array}$ & \\
\hline$\beta_{41}$ & $\Delta T F_{t}$ & & $\begin{array}{l}0.040 \\
(1.09)\end{array}$ & & $\begin{array}{l}0.057 \\
(1.64)\end{array}$ & & $\begin{array}{l}0.054 \\
(1.60)\end{array}$ & \\
\hline$\gamma_{21}$ & $T A X_{t-1}$ & & $\begin{array}{l}0.017 \\
(1.36)\end{array}$ & & $\begin{array}{c}0.018 * \\
(1.74)\end{array}$ & & $\begin{array}{l}0.016 \\
(1.58)\end{array}$ & \\
\hline$\gamma_{41}$ & $\Delta T A X_{t}$ & & $\begin{array}{l}0.029 \\
(1.19)\end{array}$ & & $\begin{array}{c}0.046^{*} \\
(1.83)\end{array}$ & & $\begin{array}{c}0.044^{*} \\
(1.82)\end{array}$ & \\
\hline$\eta_{61}$ & $\Delta M_{t}^{l}$ & & $\begin{array}{l}0.036 \\
(1.23) \\
\end{array}$ & & $\begin{array}{l}-0.001 \\
(-0.93) \\
\end{array}$ & & $\begin{array}{l}-0.000 \\
(-0.88) \\
\end{array}$ & \\
\hline & $\mathrm{N}$ & & 454 & & 454 & & 454 & \\
\hline \multirow{2}{*}{\multicolumn{2}{|c|}{$R^{2}$}} & & 0.759 & & 0.755 & & 0.763 & \\
\hline & & & t-stat. & p-val. & t-stat. & p-val. & t-stat. & p-val. \\
\hline & $\begin{array}{l}\text { ndant FE } \\
\text { lood ratio }\end{array}$ & & 3.53 & 0.00 & 3.85 & 0.00 & 4.08 & 0.00 \\
\hline
\end{tabular}

Notes: Used robust heteroskedastic-consistent standard errors. The t-statistics are in parentheses. *, ** and *** denotes statistically significant at a 10,5 and 1 percent level, respectively. 
Table VI - Robustness tests for estimations based on specification (3)

Sample restriction

Summary results

Sample with

"central-European" countries

Some evidence of non-keynesian effects for taxes during fiscal consolidations, which holds both in the presence and absence of monetary expansions. Evidence seems stronger when fiscal consolidations are matched by monetary expansions. Could not compute several estimations due to near singular matrix problems.

Sample with "peripheral" countries

Some evidence of non-keynesian effects for all of the budgetary components, which seems to be stronger when fiscal consolidations are matched by monetary expansions. Could not compute some estimations due to near singular matrix problems.

$1970-1998$

Some evidence of non-keynesian effects for all of the budgetary components, which seems to be stronger when fiscal consolidations are matched by monetary expansions.

$1999-2012$ We could not compute any estimation due to near singular matrix.

Notes: "Central-European" countries include all but Greece, Ireland, Italy, Portugal and Spain, which are labelled as peripheral countries. Estimations are available on request. 
Table VII - Successful fiscal consolidations according to the different criteria (1970-2012)

\begin{tabular}{|c|c|c|c|c|c|c|}
\hline & \multicolumn{3}{|c|}{$S U^{1}$} & \multicolumn{3}{|c|}{$S U^{2}$} \\
\hline Country & $F C^{1}$ & $F C^{2}$ & $F C^{3}$ & $F C^{1}$ & $F C^{2}$ & $F C^{3}$ \\
\hline Austria & & 84,05 & 84,05 & & 01,05 & 01,05 \\
\hline Belgium & $82-84$ & $82-84$ & 82,84 & $82-87$ & & \\
\hline Denmark & $83-86$ & $83-86$ & $83-86$ & $83-87$ & $83-86$ & $83-86$ \\
\hline Finland & 97,00 & $\begin{array}{c}88,96-97, \\
00\end{array}$ & $88,96,00$ & $97-98$ & $88,96-97$ & $88,96,00$ \\
\hline \multicolumn{7}{|l|}{ France } \\
\hline Germany & 96,99 & 96,11 & 96,11 & $96-99$ & & \\
\hline Greece & $\begin{array}{c}93-94, \\
10-11 \\
\end{array}$ & $\begin{array}{c}91,94,10- \\
11\end{array}$ & $\begin{array}{r}91,94, \\
10-11\end{array}$ & 96 & & \\
\hline Ireland & 11 & 88,11 & 88,11 & & 88 & 88 \\
\hline Italy & 92 & 82,92 & 82,92 & $92-94$ & & \\
\hline Netherlands & 91 & 91 & 91 & 93 & 93,96 & 93,96 \\
\hline Portugal & 83,11 & $83,88,11$ & $83,88,11$ & & 86,88 & 86,88 \\
\hline \multicolumn{7}{|l|}{ Spain } \\
\hline Sweden & 97 & $96-97$ & $96-97$ & $97-99$ & $96-97$ & $96-97$ \\
\hline $\begin{array}{c}\text { United } \\
\text { Kingdom }\end{array}$ & $97-99,11$ & $97-98,11$ & 11 & $97-00$ & $97-98,00$ & 00 \\
\hline $\begin{array}{c}\# \\
\text { Successful } \\
\text { years } \\
\end{array}$ & 25 & 32 & 28 & 29 & 19 & 17 \\
\hline
\end{tabular}

Source: author's computations. Notes: $S U^{1}$ - Success measure based on Afonso \& Jalles (2012); $S U^{2}$ Success measure based on Alesina \& Ardagna (2013); $F C^{l}$ - Measure based on Giavazzi \& Pagano (1996); $F C^{2}$ - Measure based on Alesina \& Ardagna (1998); $F C^{3}$ - Measure based on Afonso (2006, 2010). 
Table VIII - Success of fiscal consolidations for $S U^{1}$ based on $F C^{2}$

\begin{tabular}{|c|c|c|c|c|c|c|}
\hline \multirow[b]{2}{*}{ Specification } & \multicolumn{3}{|c|}{ Expenditure } & \multicolumn{3}{|c|}{ Revenue } \\
\hline & 1 & 2 & 3 & 4 & 5 & 6 \\
\hline constant & $\begin{array}{c}-4.930 * * * \\
(-3.17)\end{array}$ & $\begin{array}{c}-3.842 * * * \\
(-2.93)\end{array}$ & $\begin{array}{c}-3.851 * * * \\
(-2.97)\end{array}$ & $\begin{array}{c}-3.171 * * * \\
(-2.79)\end{array}$ & $\begin{array}{c}-2.962 * * \\
(-2.48)\end{array}$ & $\begin{array}{c}-2.962 * * \\
(-2.48)\end{array}$ \\
\hline duration & $\begin{array}{c}1.177 * * \\
(1.99)\end{array}$ & $\begin{array}{c}0.974^{*} \\
(1.93)\end{array}$ & $\begin{array}{c}0.975^{*} \\
(1.94)\end{array}$ & $\begin{array}{c}0.860^{*} \\
(1.87)\end{array}$ & $\begin{array}{c}0.828^{*} \\
(1.72)\end{array}$ & $\begin{array}{c}0.828^{*} \\
(1.72)\end{array}$ \\
\hline$\Delta c a p b$ & $\begin{array}{c}1.178 * * * \\
(3.34)\end{array}$ & $\begin{array}{c}1.006^{* * * *} \\
(3.23)\end{array}$ & $\begin{array}{c}1.009 * * * \\
(3.29)\end{array}$ & $\begin{array}{c}0.873 * * * \\
(3.01)\end{array}$ & $\begin{array}{c}0.870 * * * \\
(2.89)\end{array}$ & $\begin{array}{c}0.870^{* * * *} \\
(2.89)\end{array}$ \\
\hline $\exp 12$ & $\begin{array}{c}1.443 * * * \\
(3.14)\end{array}$ & & & & & \\
\hline $\exp 23$ & & $\begin{array}{c}0.783^{*} \\
(1.70)\end{array}$ & & & & \\
\hline $\exp 34$ & & & $\begin{array}{l}0.783^{*} \\
(1.70)\end{array}$ & & & \\
\hline rev12 & & & & $\begin{array}{l}0.059 \\
(0.12)\end{array}$ & & \\
\hline rev23 & & & & & $\begin{array}{l}-0.296 \\
(-0.62)\end{array}$ & \\
\hline rev34 & & & & & & $\begin{array}{l}-0.296 \\
(-0.62)\end{array}$ \\
\hline$m \times 2$ & $\begin{array}{l}0.031 \\
(0.06)\end{array}$ & $\begin{array}{l}0.055 \\
(0.11)\end{array}$ & $\begin{array}{l}0.059 \\
(0.11)\end{array}$ & $\begin{array}{l}0.343 \\
(0.57)\end{array}$ & $\begin{array}{l}0.243 \\
(0.46)\end{array}$ & $\begin{array}{l}0.243 \\
(0.46)\end{array}$ \\
\hline$R^{2}$ & 0.487 & 0.414 & 0.414 & 0.381 & 0.386 & 0.386 \\
\hline$N$ & 50 & 50 & 50 & 50 & 50 & 50 \\
\hline
\end{tabular}

Notes: Used robust heteroskedastic-consistent standard errors. The t-statistics are in parentheses. $*, * *$ and *** denotes statistically significant at a 10,5 and 1 percent level, respectively. 12, 23 and 34 next to exp and rev refer to the relevant value for $\lambda$, according to (6). 
Table IX - Success of fiscal consolidations for $S U^{2}$ based on $F C^{1}$

\begin{tabular}{|c|c|c|c|c|c|c|}
\hline \multirow[b]{2}{*}{ Specification } & \multicolumn{3}{|c|}{ Expenditure } & \multicolumn{3}{|c|}{ Revenue } \\
\hline & 1 & 2 & 3 & 4 & 5 & 6 \\
\hline constant & $\begin{array}{l}-1.672 \\
(-1.41)\end{array}$ & $\begin{array}{l}-1.690 \\
(-1.42)\end{array}$ & $\begin{array}{l}-1.884 \\
(-1.41)\end{array}$ & $\begin{array}{l}-0.850 \\
(-0.90)\end{array}$ & $\begin{array}{l}-0.519 \\
(-0.52)\end{array}$ & $\begin{array}{l}-0.519 \\
(-0.52)\end{array}$ \\
\hline duration & $\begin{array}{c}0.821 * * \\
(2.56)\end{array}$ & $\begin{array}{c}0.832 * * * \\
(2.61)\end{array}$ & $\begin{array}{c}0.860^{* * *} \\
(2.42)\end{array}$ & $\begin{array}{c}0.720 * * * \\
(3.06)\end{array}$ & $\begin{array}{c}0.923 * * * \\
(3.41)\end{array}$ & $\begin{array}{c}0.923 * * * \\
(3.41)\end{array}$ \\
\hline$\Delta c a p b$ & $\begin{array}{c}-0.262^{* *} \\
(-2.03)\end{array}$ & $\begin{array}{c}-0.263 * * \\
(-2.04)\end{array}$ & $\begin{array}{c}-0.221 * \\
(-1.87)\end{array}$ & $\begin{array}{c}-0.233^{*} \\
(-1.70)\end{array}$ & $\begin{array}{c}-0.404 * * * \\
(-2.65)\end{array}$ & $\begin{array}{c}-0.404 * * * \\
(-2.65)\end{array}$ \\
\hline $\exp 12$ & $\begin{array}{c}1.600 * * \\
(2.48)\end{array}$ & & & & & \\
\hline $\exp 23$ & & $\begin{array}{c}1.601 * * \\
(2.46)\end{array}$ & & & & \\
\hline $\exp 34$ & & & $\begin{array}{c}1.938^{* * *} \\
(2.49)\end{array}$ & & & \\
\hline rev12 & & & & $\begin{array}{l}-0.317 \\
(-0.55)\end{array}$ & & \\
\hline rev23 & & & & & $\begin{array}{c}-1.571 * * \\
(-1.99)\end{array}$ & \\
\hline rev34 & & & & & & $\begin{array}{c}-1.571 * * \\
(-1.99)\end{array}$ \\
\hline$m \times 2$ & $\begin{array}{l}-0.382 \\
(-0.69)\end{array}$ & $\begin{array}{l}-0.389 \\
(-0.70)\end{array}$ & $\begin{array}{l}-0.238 \\
(-0.40)\end{array}$ & $\begin{array}{l}-0.175 \\
(-0.33)\end{array}$ & $\begin{array}{l}-0.410 \\
(-1.67)\end{array}$ & $\begin{array}{l}-0.410 \\
(-1.67)\end{array}$ \\
\hline$R^{2}$ & 0.478 & 0.477 & 0.511 & 0.352 & 0.440 & 0.440 \\
\hline$N$ & 39 & 39 & 39 & 39 & 39 & 39 \\
\hline
\end{tabular}

Notes: Used robust heteroskedastic-consistent standard errors. The t-statistics are in parentheses. *, ** and *** denotes statistically significant at a 10,5 and 1 percent level, respectively. 12, 23 and 34 next to exp and rev refer to the relevant value for $\lambda$, according to (6). 
Table X - Robustness tests for estimations based on specification (8)

\begin{tabular}{|c|c|}
\hline Sample restriction & Summary results \\
\hline $\begin{array}{l}\text { Sample with } \\
\text { "central-European" } \\
\text { countries }\end{array}$ & Similar pattern, compared to the unrestricted case. \\
\hline $\begin{array}{l}\text { Sample with "periphery" } \\
\text { countries }\end{array}$ & $\begin{array}{l}\text { We could not compute any estimation, except for the SU2 case, due to lack of } \\
\text { variability of some variables. Didn't get statistically significant results except for } \\
\text { expenditure based adjustments. Those coefficients have the same signal as in the } \\
\text { unrestricted case. }\end{array}$ \\
\hline $1970-1998$ & $\begin{array}{l}\text { Similar pattern for the SU1 case. In the SU2 case, the results are similar to the ones } \\
\text { found for the unrestricted sample, except for the size of the consolidations, which } \\
\text { didn't turn any statistically significant results. }\end{array}$ \\
\hline $1999-2012$ & We could not compute any estimation due to lack of variability of some variables. \\
\hline
\end{tabular}

Notes: "Central-European" countries include all but Greece, Ireland, Italy, Portugal and Spain, which are labelled as periphery countries. Estimations are available on request. 


\section{Appendix}

Table A1 - Data sources

\begin{tabular}{|c|c|}
\hline Original Series & $\begin{array}{l}\text { AMECO } \\
\text { Code }\end{array}$ \\
\hline Total population, thousands. & NPTN \\
\hline Gross domestic product, millions, national currency, current market prices. & UVGD \\
\hline Price deflator of gross domestic product, national currency, $2005=100$. & PVGD \\
\hline Private final consumption expenditure at 2005 constant prices, millions, national currency. & $\mathrm{OCPH}$ \\
\hline $\begin{array}{l}\text { Final consumption expenditure of general government at } 2005 \text { constant prices, millions, national } \\
\text { currency. }\end{array}$ & OCTG \\
\hline $\begin{array}{l}\text { Social benefits other than social transfers in kind, general government, millions, national } \\
\text { currency, current prices. }\end{array}$ & UYTGH \\
\hline $\begin{array}{l}\text { Current taxes on income and wealth (direct taxes), general government, millions, national } \\
\text { currency, current prices. }\end{array}$ & UTYG \\
\hline $\begin{array}{l}\text { Total expenditure: general government: ESA } 1995 \text { (Including one-off proceeds (treated as } \\
\text { negative expenditure) relative to the allocation of mobile phone licenses (UMTS)). }\end{array}$ & UUTG \\
\hline Total revenue: general government: ESA 1995. & URTG \\
\hline $\begin{array}{l}\text { General government consolidated gross debt: Excessive deficit procedure (based on ESA 1995) } \\
\text { and former definition (linked series); \% GDP }\end{array}$ & UDGGL \\
\hline $\begin{array}{l}\text { Taxes linked to imports and production (indirect taxes), general government, millions, national } \\
\text { currency, current prices. }\end{array}$ & UTVG \\
\hline $\begin{array}{l}\text { Net borrowing }(+) \text { or net lending (-) excluding interest of general government adjusted for the } \\
\text { cyclical component. Adjustment based on potential GDP excessive deficit procedure (\% of GDP } \\
\text { at market prices). }\end{array}$ & UBLGBP \\
\hline Real short-term interest rates, deflator private consumption. & ISRC \\
\hline $\begin{array}{l}\text { Nominal Effective exchange rate 2005=100: Performance relative to the rest of } 24 \text { industrial } \\
\text { countries: double export weights: EU-15, TR CH NR US CA JP AU MX and NZ. }\end{array}$ & XUNNQ \\
\hline Real effective exchange rate, consumer price index deflated; $2005=100$; IMF Statistics Databa & \\
\hline
\end{tabular}

